\title{
Toleransi Beragama Perspektif Wahdat Al-Wujūd Ibnu Arabi
}

\section{Sugianto}

IAI An-Nur Lampung

Sugiantoalfaruqi3@gmail.com

\begin{abstract}
Religion is a life guide for adherents to create peace and harmony in life, but lately emerged the exclusive and radical religious nature, so that gave birth to extreme phenomena and intolerance in religion. One Muslim intellectual, Ibn Arabi, has a concept that can be used as a solution to the problem above, the concept is known as the concept of a single unity (wahdat al-wujud). This paper aims to find out how the concept of the unity of a single form in shaping religious tolerance. This research belongs to library research and uses descriptive analysis method. In the concept of wahdat al-wujud Ibn Arabi, contained the nature of Inclusive and permissive in religion, this character is the foundation in realizing a peaceful and harmonious civilization. Everything that exists is a manifestation of an intrinsic being, that is a form that must exist (mandatory al-wujud). This form is reflected in three levels, namely: ahadiyah, wahiddiyah and tajalli syuhudi. So that religion from spiritual or esoteric treasures can greet each other and avoid intolerant attitudes in religion.
\end{abstract}

Keyword : Toleration, Wahdat al-Wujūd, Spiritual

Abstrak : Agama adalah panduan hidup bagi pemeluknya agar tercipta kedamaian dan keharmonisan dalam kehidupan, namun akhirakhir ini muncul sifat beragama yang eksklusif dan radikal, 
sehingga melahirkan fenomena ekstrim dan intoleran dalam beragama. Salah satu Intelektual muslim yakni Ibnu Arabi mempunyai konsep yang dapat dijadikan solusi bagi permasalahan diatas, konsep itu dikenal dengan konsep kesatuan wujud tunggal (wahdat al-wujud). Tulisan ini bertujuan untuk mengetahui bagaimana konsep kesatuan wujud tunggal dalam membentuk toleransi beragama. Penelitian ini tergolong dalam penelitian kepustakaan dan menggunakan metode diskriptif analisis. Di dalam konsep wahdat al-wujud Ibnu Arabi, terkandung sifat Inklusif dan permisif dalam beragama, karakter inilah sebagai landasan dalam mewujudkan peradaban yang damai dan harmonis. Segala sesuatu yang ada merupakan manefestasi dari wujud hakiki, yaitu wujud yang wajib ada (wajib al-wujud). Wujud tersebut tercermin dalam tiga level, yaitu: ahadiyah, wahiddiyah dan tajalli syuhudi. Sehingga agama dari khasanah spiritual atau esoteris bisa saling menyapa dan terhindar dari sikap intoleran dalam beragama.

Keywords: Toleransi, Wahdat al-Wujūd, Spiritual

\section{A. Pendahuluan}

Keragaman merupakan suatu keniscayaan dalam kehidupan manusia. Sebagaimana hakekat manusia itu sendiri, bahwa manusia merupakan makhluk yang historis dalam suatu rangkaian antropological constanst. ${ }^{1}$ Diantara domain utama sebagai akibat dari globalisasi dicirikan dengan beragamnya peradaban dan kepercayaan, yaitu menumbuhkan sikap toleransi atas segala perbedaan yang ada. Karena pada hakikatnya semuanya adalah karya cipta illahi yang terjalin dalam satu ekosistem.

Akan tetapi data berkata lain, Indonesia yang notabene multikultural telah mengalami berbagai peristiwa yang melibatkan perbedaan keyakinan dan golongan. Hal ini disebabkan oleh penggunaan simbol agama sebagai legitimasi terhadap tindakan yang

1 Kathlen Anne McManus, Unbroken Communion: The Place and Meaning of Suffering in the theology of edward Schillebeeckx, (Ney York: 1959), h. 79. 
dilakukannya. Tindakan kekerasan atas nama agama sebagaimana dalam laporan tahunan Wahid Institut menyatakan bahwa pada tahun 2016 jumlah pelanggaran meningkat tujuh persen, pada tahun ini tercatat 204 kasus dengan 313 tindakan pelangnggaran KBB (kemerdekaan beragama dan berkeyakinan). Sementara tahun 2015, tercatat 190 kasus dengan 249 tindakan pelanggaran. $^{2}$

Pelanggaran terhadap KBB dapat dilihat pada diagram berikut:

Diagram 1.

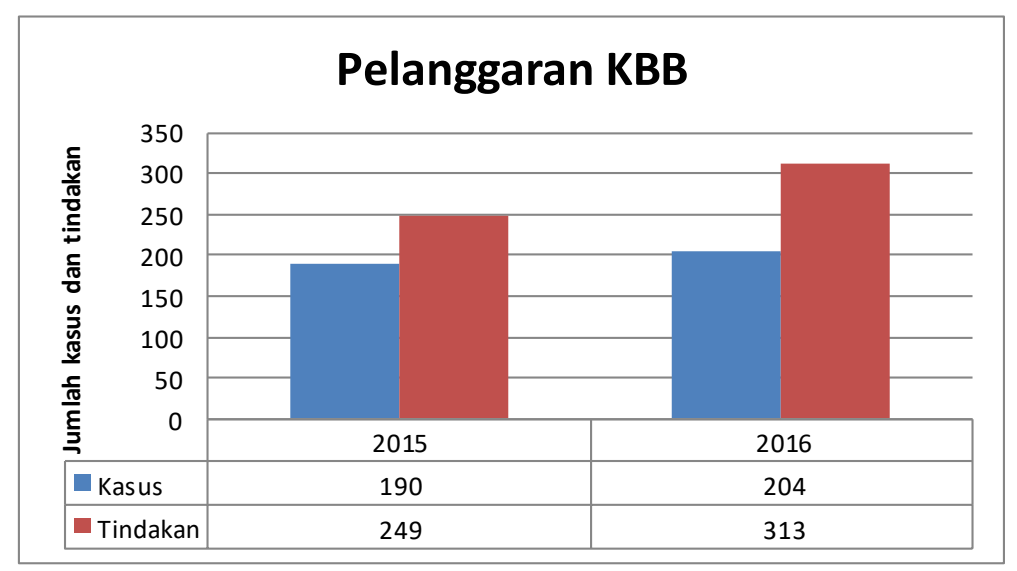

Kasus tersebut, jika ditelusuri secar teologis, maka ditemukan adanya perbedaan pemahaman terhadap keyakinan. Deretan peristiwa tersebut sangat mengusik keharmonisan dalam kehidupan beragama, berbangsa dan bernegara, karena telah masuk pada kejahatan terhadap nilai-nilai kemanusiaan. Pada titik ini, agama tampaknya tidak menjadi sebuah kekuatan pendorong terhadap cita-cita sebuah tatanan yang rahmatan lil alamīn. Agama juga bukan lagi sebuah entitas yang mampu memberikan kedamaian, kesejukan, dan keramahan bagi terciptanya keharmonisan sosial beragama.

Kondisi yang demikian telah mengundang banyak akademisi untuk mengkajinya sebagai upaya untuk mencarikan solusinya. Salah satunya adalah Ibnu Arabi. beliau menciptakan pemahaman secara makro yang dikenal dengan konsep wahdat al-wujūd. Konsep ini

2 Suhendra, Kasus kekerasan beragama meningkat, dalam https://www.nu.or.id/post/read/75785/yenny-wahid-tahun-2016-kasus-kekerasanberagama-meningkat. Diakses pada tanggal 7 Agustus 2019. 
merupakan pengalaman puncak yang telah dicapai oleh Ibnu Arabi dalam pengembaraan spiritualnya.

Pembahasan tentang pemikiran tokoh ini tentu sudah banyak yang meneliti, diantaranya peneltian yang dilakukan oleh Arma yang berjudul kesatuan agama-agama dan kearifan perenial dalam perspektif tasawuf, dalam penelitian ini membahas bahwa agama jika dilacak dalam tataran inti ajaran agama, akan didapati sebuah pesan yang sama, yaitu terwujudnya kedamaian, kebaikan dan kebahagian bagi manusia. Tidak ada agama yang mengajarkan kekerasan dan kebiadaban. Keadaan tersebut semakin memperkuat bahwa dalam perspektif teologis agama sangat membutuhkan terciptanya kesejahteraan dalam kehidupan manusia. Maka setiap manusia mempunya kewajiban yang sama, yaitu mewujutkan ketentraman dalam kehidupan sosial. ${ }^{3}$

Sedangkan Penelitian Kholil Karomi menghasilakan sebuah kesimpulan, bahwa para sufi telah memberikan legitimasi terhadap paham pluralisme agama, terutama konsep yang diberikan oleh ibnu Arabi, yakni kesatuan wujud. ${ }^{4}$ Berbeda dengan kholil, Muzakir mengahasilkan sebuah kesimpulan bahwa manusia dalam persepktif sufi sebagai kesatuan makhluk yang bernaung di bawah kasih sayang tuhan. $^{5}$

Dalam penelitian ini peneliti akan membahas bagaimana konsep Wahdat al-Wujūd Ibnu Arabi dalam membentuk toleransi beragama. Penelitian ini tergolong dalam penelitian pustaka dan menggunakan metode diskriptif analisis. Berdasarkan teori wahdat al-wujūd, manusia mengemban amanah untuk menciptakan kehidupan yang damai dan harmonis, baik dalam beragama, ras, suku, budaya maupun dengan bangsa lain. Menyakini kebenaran faham yang digenggam, bukan berarti berhak ikut andil dalam menghakimi, menjelekkan dan menyalahkan kebenaran yang diyakini oleh orang lain.

${ }^{3}$ Armia, "Kesatuan agama-agama dan kearifan perenial dalam perspektif tasawuf”. Dalam Jurnal al-Tahir, vol.13, No. 1 (Mei 2013).

${ }^{4}$ Kholil Karomi, "Penolakan Ibnu Arabi Terhadap Pluralisme Agama. Dalam Jurnal Kalimah, vol. 12, No. I (Maret 2014).

${ }^{5}$ H. Muzakir." Toleransi beragama dan mahabbah dalam perspektif sufi." Dalam jurnal Teologi, Vol.23. No. 2.(Januari 2012). 


\section{B. Konsep Toleransi}

Makna toleransi jika ditinjau dari segi leksikal bahasa Indonesia bermakna sifat atau sikap meneggang dan pendirian. ${ }^{6}$ Sehingga dari sudut ini dapat dipahami bahwa toleransi adalah sikap dan sifat yang masih diperbolehkan dan tidak melebihi ambang batas. Berbeda jika toleransi dilihat dari bahasa Arab, yakni tasamuh terambil dari kata dasar sa mim dan ha (samaha) yang bermakna ampun, maaf dan lapang dada. ${ }^{7}$

Lebih lanjut, Dewan Ensiklopedia Nasional Indonesia memberikan batasan terhadap makna toleransi pada sikap menerima keberagaman dan keanekaragaman agama dan keyakinan orang lain. ${ }^{8}$ Hal ini senada dengan pendapat Poerwadarminto, bahwa toleransi merupakan sifat atau sikap menerima dan menghargai adanya perbedaan yang merupakan suatu keniscayaan dalam dunia ini. ${ }^{9}$ Adapun legitimasi toleransi dalam islam terkandung pada surat alkafirun ayat 1-6. Dari surat ini dapat diambil mafhumul ayat diantaranya: 1) siapapun tidak boleh dipaksa untuk menerima atau meninggalkan agamanya, 2) dalam diri individu mempunya hak kebebasan beragama. ${ }^{10}$ Dengan adanya ayat ini semakin jelas makna dari toleransi itu sendiri.

Dari berbagai pendapat di atas dapat digolongkan dua penafsiran. Pertama, makna negatif, toleransi terkesan membiarkan orang lain untuk berbuat sesuka hatinya. Sedangkan yang kedua, bermakna positif, yaitu dukungan dan bantuan kepada makluk lain atau orang lain. ${ }^{11}$

Dengan demikian makna toleransi secara aplikatif, yakni suatu sifat kelapangan dada terhadap perbedaan yang ada, baik dalam

${ }^{6}$ Tim penyusun, KBBI (Kamus Besar bahasa Indonesia), (Jakarta: Pusba Departemen Pendidikan nasional, 2008), h. 1538.

7 Ahmad Warson Munawir, Kamus Arab-Indonesia al Munawir, (Yogyakarta: Balai Pustaka Progresif, tt.h), h. 1098.

${ }^{8}$ Ensiklopedia Nasional Indonesia, Jakarta: Cipta Aditiya, 1991), h. 384.

9 W. J. S. Peorwadarminto, Kamus Umum Bahasa Indonesia, (Jakarta: Balai Pustaka, 1986), h. 184.

${ }^{10}$ Departemen Agama RI, Hubungan Antara Umat Beragama, (Tafsir AlQur'an Tematik), (Jakarta: Departemen Agama 2008), h. 83-86.

11 Masykuri Abdullah, Pluralisme Agama dan Kerukunan dalam Keragaman, (Jakarta: Kompas, 2001), h. 13. 
masalah pendapat, keyakinan, agama, ekonomi, politik dan status sosial.

\section{Toleransi Perspektif Ajaran Wahdat al -Wujūd}

Keragaman dalam agama, ras, budaya, suku, bahasa dan bangsa merupakan suatu keniscayaan. Hal tersebut merupakan bukti adanya pluralitas dalam kehidupan manusia. Salahsatunya adalah pluralitas agama yang kemudian mewujud menjadi realitas sosial yang menyejarah dalam kehidupan umat manusia. Karena itu, secara historis dikenal banyak umat agama dan kepercayaan seperti: nasrani, buda, hindu, konghucu dan Islam.

Dalam kontek pluralitas tersebut, maka toleransi menjadi kunci dalam menyikapinya. Secara normatif, toleransi menjadi core ajaran Islam. Konsep tersebut sebanding dengan ajaran yang lain, seperti kasih sayang (rahmah), kebijaksanaan (hikmah), kemaslahatan universal (al-maslahah al-ammah), dan keadilan.

Toleransi jika dirujuk dari makna leksikal diatas, maka akan didapati beberapa makna turunan, yakni: 1) sifat dan sikap, 2).nilai ambang batas yang diperbolehkan, 3). Batas minimal penyimpangan. ${ }^{12}$ Berbeda dengan batasan yang diberikan oleh Atabik dan Ahmad Azuhudi Muhdlor, mereka membatasi toleransi dengan makna membolehkan. ${ }^{13}$ Sedangkan makna serapan, yakni bahasa latin "tolerare" memiliki batasan arti dengan sabar membiarkan sesuatu. Dari paparan makna mantū $q$ di atas secara umum batasan makna toleransi adalah sikap memberikan izin kepada seseorang sesuai batas normal.

Jika konsep tersebut diterapkan dalam beragama, Islam telah melegitimasi bahwa kebebasan menjalankan keyakinan agama baik muslim maupun non muslim merupakan bagian dari syari'at Islam. Hal tersebut tercermin pada Q.S. al-Kafirūn ayat 6 dan Q.S. alBaqoroh ayat 256. Pada ayat ini memberikan legitimasi kepada semua manusia mengenai hak asasi manusia tentang beragama sesuai yang diyakininya tanpa ada paksaan dari siapapun. Mafhum dari ayat ini

${ }^{12} \mathrm{KBBI}$, pusat bahasa, h. 1478.

13 Atabik ali dan ahmad zuhudi muhdlor, kamus kontemporer arab indonesia, (yogyakarta: yayasan ali maksum pondok pesanten krapayak, 1996), h. 1083-1086. 
yakni beragama merupakan atas dasar kesadaran diri secara utuh bukan karena paksaan dari pihak manapun.

Mengenai hak untuk menentukan kepercayaan sesuai yang diyakininya, berdasar ayat di atas dapat di ambil mafhūm al-ayat sebagai berikut:

1. Kebebasan bagi umat beragama untuk memeluk agamanya masing-masing. ${ }^{14}$

2. Jika sudah beragama Islam, tidak sebebasnya mengganti sesuai kehendaknya.

3. Islam memberikan pilihan bagi pemeluknya menjalankan ajaran agamanya sepanjang tidak melanggar aturan syari'at dan aqidah. ${ }^{15}$

Berdasarkan uraian tersebut, mengenai toleransi, Islam sangat menjunjung tinggi dan bahkan mewajibkan untuk bertoleransi. Akan tetapi anjuran toleransi dalam ayat tersebut masih bersifat mutlaq dan memerlukan muqoyad atau batasan dari kemutlakan makna tersebut. Yaitu toleransi tanpa ikut campur dalam ibadah dan keyakinan orang lain.

Pemaknaan toleransi yang telah dipaparkan diatas jika di tarik dalam ilmu tafsir masuk dalam kategori tafsir bil ma'sur. Berbeda dengan toleransi dari perspektif tasawuf, para sufi ketika menafsirkan ayat al-qur'an dapat digolongkan kedalam tafsir isyāri. Metode tafsir isyāri inilah yang digunakan oleh Ibnu Arabi dalam menafsirkan ayat-ayat al-qur'an, sehingga dikemudian hari hasil penafsiran beliau jika dikomparasikan dengan metode tafsir yang lain banyak menimbulkan kontroversi terutama bagi Islam eksoteris.

Kecendrungan kaum sufi ketika hendak mengurai makna terhadapa suatu teks, selalu berpedoman pada kaedah deept structure (struktur dalam) dan surface structure (struktur luar). Dengan berpedoman pada kaedah tersebut akan didapatkan makna yang komprehensip dari suatu teks. Mereka sangat intens terhadap aspek batin tanpa mengabaikan aspek lahirnya.

${ }^{14}$ Muddathir Abdurrahim, dalam The Human Rights Tradition in Islam (London: Praeger, Westport, Connecticut, 2005), h. 170-171.

${ }^{15}$ Sulieman Abdurrahman al-Hageel, Human Right in Islam and Refutation of the Misconceived Allegation Associated with These Right (Riyadh: Dar Eshbelia, t.th), h. 82-83. 
Lebih lanjut, dengan metode tafsir yang telah mereka kembangkan yang populer dengan istilah tafsir isyāri berupaya mengungkap makna mantuq maupun mafhum pada teks suci (alQur'an dan Hadis) melalui pendekatan yang menyeluruh, yakni pendekatan makna dhahir, makna dalam, makna devinisi dan makna matla $^{16}$. Dalam hal ini ibnu arabi membuat batasan yang dimaksut dengan dhahir yakni makna berdasarkan tafsir mantuq, sedangkan makna batin merupakan sesuatu yang hendak dituju dari proses perjalanan pencarian makna segala realitas yang ada. Dengan ungkapan lain bahwa makna dhahir yaitu makna berdasar pada mazazi atau syari'at, sedangkan makna batin ungkapan lain dari makna hakiki. ${ }^{17}$

Filsafat Wahdat al-wujūd memantapkan diri dengan temuan bahwa yang ada hanyalah wujud yang satu, semua yang ada ini hanyalah manifestasi dari yang ada itu sendiri. Wujud yang satu ini adalah Allah ta'ala, yang satu itu mencakup atas semua fenomena yang ada dan merupakan sumber daya akal yang memancar keseluruhan alam semesta. Dalam konteks ini Dia disebut hakekat nur muhammad. Yang Satu itu adalah sumber dari kosmos yang mengatur alam semesta, maka Dia disebut Jiwa Universal. Yang Satu itu menampakkan perbuatannya pada masing-masing wujud yang ada di alam semesta, maka Dia disebut dengan tubuh Universal. Yang satu itu bila dilihat dari keberadaannya sebagai satu jauhar yang menghadap pada seluruh bentuk-bentuk kejadian maka dia berada dalam bentuk al-haba', ${ }^{18}$

Kemudian oleh Musa menyederhanakan konsep tersebut yaitu segala relitas pada hakekatnya tidak ada, kecuali diadakan oleh yang ada. Tidak ada itu ada karena adanya yang ada, sehingga realitas ini adalah manifestasi dari yang ada itu sendiri. ${ }^{19}$

${ }^{16}$ Makna lahir ayat adalah bacaan, batin adalah ta'wilnya, hadd adalah hukum-hukum tentang halal dan haram, sedangkan matla' adalah tujuan Allah dari hambanya dengan ayat itu sendiri( Ibnu Arabi, Fusus al-hikam, th, h. 21)

${ }^{17}$ Ibnu 'Arabi, Fusus al Hikam, tth, h. 302.

18 William C. Chittick, The Sufi Path of Knowledge: Ibn al-'Arabi's Metaphysics of imagination, (New York: state university of new york pres, 1989), h.80., Noer, Ibn Arabi; Wahdat Al-Wujud Dalam Perdebatan, h. 35.

${ }^{19}$ M. Yusuf Musa, Falsafat al Akhlaq fi al Islam, (Kairo:Muassasah al Khanji, 1963), h. 248. 
Berdasarkan konsep diatas, dapat di jadikan dasar sebagai world view atau kacamata dalam melihat realita. Bahwa realita sebagai fenomena ini memiliki nalar logikanya, dalam setiap fenomena terdapat neumena dan didalam neumena terdapat $f a$ 'il haqiqi sebagai penggerak realitas yang ada atau fa'il majazi. ${ }^{20}$ Kesadaran realitas tersebut oleh Ibnu Arabi diekstrak menjadi konsep alam makro kosmos dan mikro kosmos. Secara rinci beliau memaparkan konsep tersebut, yaitu:

\section{Martabat Ahadiyah}

Wujud Tuhan merupakan zat Mutlak lagi Mujarrad, tidak bernama dan tidak bersifat. Karena itu, Ia tidak dapat dipahami atapun dikhayalkan. Pada level ini, Tuhan (sering diistilahkan al-Haq oleh bnu 'Arabi) berada dalam keadaan murni bagaikan kabut yang gelap ( $F$ i al-'ama), yang mumpunyai makna tidak sesudah, tidak sebelum, tidak terikat, tidak terpisah, tidak ada atas, tidak ada bawah, tidak mempunyai nama, tidak musammā (dinamai). Pada level ini, al-Haq tidak dapat dikomunikasikan oleh siapapun dan tidak dapat diketahui.

Pada level ini, cara satu-satunya untuk memahami Tuhan yaitu melaui Teologi Negatif. ${ }^{21}$ Teologi negatif merupakan diskursus yang kurang lazim dalam kalangan pengkaji agama. Sebagaimana diungkapkan oleh Turner, bahwa teologi negatif tidak perlu didevinisikan. Berbeda dengan pandangan Turner, Mary membahasakan teologi negatif dengan ungkapan bahasa negatif (-). ${ }^{22}$

Kesukaran terhadap batasan dari Teologi negatif tersebut karena tidak ada Ijma' (konsensus) dari para ahli, sehingga batasan mengenai teologi negatif diberikan kepada setiap orang untuk mengisinya masing-masing, yaitu sesuai otoritas keilmuan yang dimiliki oleh setiap orang. ${ }^{23}$

${ }^{20}$ Ibnu 'Athoilah, Syarah al Hikam, h. 3.

${ }^{21}$ Deny Turner, The Darkness of god: Negatif in Christian Mysticism, (Cambridge: Cambridge University Press, 1995).

${ }^{22}$ Mary-Jane Rubenstan, "Unknow Thyself: Apophaticism, Decontruction, and Theologi after Ontotheology,"Modern Theology, 19 (July 2003), h. 394.

${ }^{23}$ Derida, Pscyhe: Inventions de I'autre, (Paris: Galilee, 1987), h. 535. 


\section{Martabat Wahiddiyah}

Yaitu penampakan pertama (ita'ayyun awwali) atau disebut juga faydh al-aqdas (emanasi paling suci). Dilevel ini, zat yang mujarrad itu bermanifestasi melaui sifat dan asma-Nya. Dengan manifestasi atau tajali ini, zat yang Maha sempurna dinamakan Allah, dengan Sifat dan Nama yang Mahasempurna (al-asma al-husna, Allah). Akan tetapi, sifat dan nama itu sendiri identik dengan zat. Disini kita berhadapan dengan zat Allah yang maha Esa, tetapi Ia mengandung di dalam diri-Nya berbagai bentuk potensial dari hakekat alam semesta atau entitas permanen (al- 'a'yan tsabitah).

\section{Martabat Tajjali Syuhudi}

Martabat ini disebut juga dengan faidh al-muqaddas (emsnasi suci) dan ta'ayyun tsabi (entifikasi kedua, atau penampakan diri peringkat kedua). Pada martabat ini Allah Swt bertaali melalui asma dan sifat-Nya dalam keyataan empiris atau alam kasat mata. Dengan kata lain, melaui firman kun (jadilah), maka entitas permanen seca aktual menelma dalam berbagai citra atau bentuk alam semesta. Dengan demikian alam ini tidak lain adalah kumpulan fenomena empiris yang merpakan lokus atau mazhar tajali al-haq. Alam yang menjadi wadah manifestasi itu sendiri merupakan wujud atau bentuk yang tidak akhirnya. Ia tidak lain laksana 'aradh atau aksiden (sifat yang datang kemudian) dan jauhar (subtansi) dalam istilah ilmu kalam. Selama ada subtansi, maka aksiden akan tetap ada. Begitu pula dalam tasawuf. Menurut ibnu 'Arabi, selama ada Allah, maka alam akan tetap ada, ia hanya muncul dan tenggelam tanpa akhir.

Berdasarkan paparan konsep tersebut dapat diambil sebuah gambaran umum mengenai beragamnya agama, bahwa adanya beraneka ragam agama bertujuan untuk memberikan kebebasan kepada setiap manusia untuk memilihnya. Setiap ajaran agama merupakan jalan untuk menuju kebenaran hakiki, namun jalan tersebut tidak sama dengan konsep Tuhan. Sebagaimana suatu zat satu dan sama, "air", disebut dengan berbagai nama sesuai bahasa yang dimilikinya. Begitujuga konsep tentang kebahagian hidup yang kekal atau konsep tentang Tuhan. ${ }^{24}$

24 Huston Smith, Agama-agama Manusia, (Jakarta: Yayasan Obor Indonesia, 1991),h. 102-103. 
Jika agama dilihat dari sudut subtansinya akan didapati sebuah kesepakatan bahwa setiap agama mengajarkan nilai-nilai kebaikan kepada setiap pemeluknya. Dari sudut ini bisa dikatakan bahwa agama secara subtansi yaitu satu, namun akan menjadi beragama atau plural ketika diturunkan di bumi, alam eksoteris dan alam nasut. Walaupun demikian setiap agama akan membawa pemeluknya ketempat asalnya, yaitu Tuhan. ${ }^{25}$ Terwujutnya kesatuan agama akan terjadi pada tataran esoteris, transenden dan wilayah batiniyah. Wilayah tersebut hanya bisa berada pada satu institusi yang secara simbolis disebut "agama", sehingga ia bersifat privat dan tertutup oleh simbol agama. Hal ini sebagaimana yang dinyatakan oleh Nurcholish Majid, yaitu siapa saja yang menginginkan biji kacang, maka ia harus mengupas kulitnya". wilayah batin akan terlihat manakala kulit luar telah dikupas, sehingga akan tampak apa yang terbungkus tersebut. ${ }^{26}$

Senada dengan pendapat Nurcholis Majid, Frithjof Schoun telah menggagas sebuah teori transendent unity of religion, bahwa setiap agama mempunyai elemen eksoteris dan esoteris. Lebih lanjut Schoun menjelaskan bahwa eksoterik merupakan bagian terluar atau bagian yang tampak dari agama tersebut, seperti ibadah formal, tata aturan ibadah dan bermuamalah (hukum). Sedangkan aspek terdalam, yakni aspek mistisisme atau dimensi terdalam dari pengalaman puncak beragama. Dari sudut inilah antar agama dapat saling menyapa dan menuju satu titik Tuhan. ${ }^{27}$

Dengan demikian, setiap umat beragama harus lebih bijak lagi dalam menanggapi perbedaan dalam beragama. Munculnya kekacauan bukan disebabkan salahnya ajaran agamanya, melainkan disebabkan oleh sudut pandang yang kurang tepat dalam melihat perbedaan tersebut. Agama pada dasarnya mengajarkan kebaikan kepada setiap pemeluknya. Akan tetapi agama tampak menjadi eksklusis diruang publik dikarenakan oknum dan tindakan kekerasan

25 Mulla Shadra bukan hanya menempatkan topik tentang pengetahuan dalam ontologi, tetapi juga menjadikan pengetahuan sebagai salah satu kategori pertama dari wujud, dan dia menempatkannya sebagai philosophia prima. Lihat Mulla Shadra, Asfar, Vol. 3, h. 278.

${ }^{26}$ Nurcholish Madjid, "Kata Pengantar" dalam Komaruddin Hidayat \& Ahmad Gaus AF (ed), Passing Over, Melintasi Batas Agama, (Jakarta: Gramedia Pustaka Utama \& Paramadina, 1998), h. xxxix.

${ }^{27}$ Frithjof Schuon, Memahami Islam, (Bandung: Pustaka, 1992), h. 250. 
atas nama agama. Hal tersebut menunjukan kesemerautan dari cara berfikir dan beragama.

\section{Implikasi Ajaran Wahdah $A l$-Wujūd Ibnu Arabi}

Ajaran Ibnu Arabi jika ditarik kedalam ranah pendidikan karakter, terutama dalam masalah toleransi beragama. Dapat dimulai dari sedini mungkin, yaitu melaui pembentukan pola pikir, sikap dan pembentukan motivasi. Tahap pertama yakni pembentukan pola pikir dengan cara pemberian wawasan mengenai nilai-nilai akhlak yang mulia dan wawasan akhlak yang tercela. Dengan berbekal wawasan tersebut seorang pelajar dapat menjustifikasi sebuah perbuatan, apakah baik atau tidak. Proses terjadinya perbuatan berdasarkan pola pikir dapat di gambarkan sebai berikut:

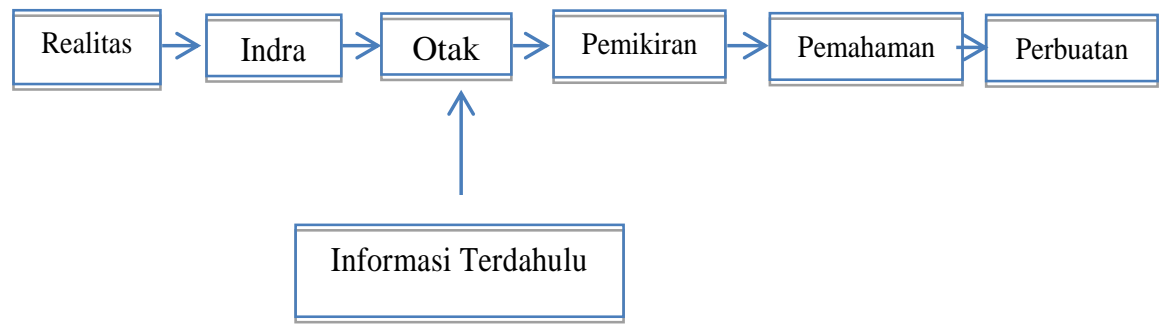

Nilai-nilai karakter yang sudah tersimpan tersebut akan memberikan pemikiran dan pemahaman kepada seseorang yang pada akhirnya akan mewujud pada sebuah perbuatan yang didasarkan pada pemahaman atas nilai karakter yang telah tertanam dalam dirinya dan akan mewujut secara spontanitas tanpa memerlukan pertimbangan dari pihak manapun. ${ }^{28}$

Tahap selanjutnya yaitu pembentukan pola jiwa, pada tataran ini cara yang dilakukan yaitu dengan mengarahkan naluri-naluri dan kebutuhan-kebutuhan jasmani manusia atas dasar pemahamanpemahaman yang telah diberikan. Maka pergerakan manusia secara alami untuk melakukan pemenuhan (dorongan-dorongan) itu harus diikat dengan pemahaman-pemahaman manusia tentang aktivitas dan segala sesuatu, hal ini disebabkan manusia hidup dalam masyarakat

${ }^{28}$ Thomas Lickona, Educating for Character: How Our School Can Teach Respect and Responsibility, (New York, Toronto, London, Sydney, Aucland: Bantam books, 1991),h. 51. 
yang menjadikan pemikiran tertentu menjadi hukum. Pemikiranpemikiran tersebut dapat mempengaruhi manusia, yang pada akhirnya menjadi pemahaman-pemahaman bagi manusia yang dipergunakan untuk menghukumi dorongan-doronganya.

Jika pemahaman tersebut memancar dari aqidah yang benar, maka pola jiwa yang muncul adalah pola jiwa yang moderat, begitu juga sebaliknya. Pola jiwa ini akan menjadikan manusia terdorong untuk melakukan perbuatan atau berpaling dari pelaksanaan perbuatan tersebut. Jadi pola jiwa ini sebagai pemutus bagi dorongan dan kecandrungan naluri.

\section{E. Kesimpulan}

Konsep wahdat al-wujud yang digagas oleh Ibnu Arabi dapat digunakan untuk membentuk toleransi beragama, implementasinya yakni dengan membentuk pola pikir dan pola jiwa berdasarkan pada tahapan Ahadiyah, Wahiddiyah dan Tajalli syuhudi. Karena, konsep wahdat al-wujūd ini sangat mementingkan kesatuan entitas dalam melihat segala sesuatu, sehingga agama dari sudut khasanah spiritual atau esoteris bisa saling menyapa dan akan melahirkan sikap torelan dan lebih bijaksana dalam kehidupan beragama.

\section{Daftar Rujukan}

Ahmad Warson Munawir, Kamus Arab-Indonesia al Munawir, (Yogyakarta: Balai Pustaka Progresif, tt.h).

Armia.," Kesatuan agama-agama dan kearifan perenial dalam perspektif tasawuf." Jurnal al-Tahir, vol.13, No. 1 (Mei 2013).

Atabik ali dan ahmad zuhudi muhdlor, kamus kontemporer arab indonesia, (yogyakarta: yayasan ali maksum pondok pesanten krapayak, 1996).

Eny Turner, The Darkness of god: Negatif in Christian Mysticism, (Cambridge: Cambridge University Press, 1995).

Departemen Agama RI, Hubungan Antara Umat Beragama, (Tafsir Al-Qur'an Tematik), (Jakarta: Departemen Agama 2008). 
Derida, Pscyhe: Inventions de I'autre, (Paris: Galilee, 1987)

Ensiklopedia Nasional Indonesia, Jakarta: Cipta Aditiya, 1991).

Frithjof Schuon, Memahami Islam, (Bandung: Pustaka, 1992).

H. Muzakir." Toleransi beragama dan mahabbah dalam perspektif sufi." Urnal Teologi, Vol.23. No. 2.(Januari 2012).

Huston Smith, Agama-agama Manusia, (Jakarta: Yayasan Obor Indonesia, 1991).

Ibnu 'Athoilah, Syarah al Hikam,.Ibnu Arabi, Fusus al-hikam, th,

Kathlen Anne McManus, Unbroken Communion: The Place and Meaning of Suffering in the theology of edward Schillebeeckx, (Ney York: 1959).

Kholil Karomi., "Penolakan Ibnu Arabi Terhadap Pluralisme Agama.” Jurnal Kalimah, vol. 12, No. I (Maret 2014).

M. Yusuf Musa, Falsafat al Akhlaq fi al Islam, (Kairo:Muassasah al Khanji, 1963).

Mary-Jane Rubenstan, "Unknow Thyself: Apophaticism, Decontruction, and Theologi after Ontotheology,"Modern Theology, 19 (July 2003).

Masykuri Abdullah, Pluralisme Agama dan Kerukunan dalam Keragaman, (Jakarta: Kompas, 2001).

Muddathir Abdurrahim, dalam The Human Rights Tradition in Islam (London: Praeger, Westport, Connecticut, 2005).

Nurcholish Madjid, "Kata Pengantar" dalam Komaruddin Hidayat \& Ahmad Gaus AF (ed), Passing Over, Melintasi Batas Agama, (Jakarta: Gramedia Pustaka Utama \& Paramadina, 1998).

Suhendra, Kasus kekerasan beragama meningkat, dalam https://www.nu.or.id/post/read/75785/yenny-wahid-tahun2016-kasus-kekerasan-beragama-meningkat. Diakses pada tanggal 7 februari 2020.

Sulieman Abdurrahman al-Hageel, Human Right in Islam and Refutation of the Misconceived Allegation Associated with These Right (Riyadh: Dar Eshbelia, t.th).

Thomas Lickona, Educating for Character: How Our School Can Teach Respect and Responsibility, (New York, Toronto, London, Sydney, Aucland: Bantam books, 1991). 
Tim penyusun, KBBI (Kamus Besar bahasa Indonesia), (Jakarta: Pusba Departemen Pendidikan nasional, 2008).

W. J. S. Peorwadarminto, Kamus Umum Bahasa Indonesia, (Jakarta: Balai Pustaka, 1986).

William C. Chittick, The Sufi Path of Knowledge: Ibn al-'Arabi's Metaphysics of imagination, (New York: state university of new york pres, 1989). 
Sugianto

Halaman ini tidak dengan sengaja dikosongkan 